DOI: 10.17951/en.2019.4.163-178

\begin{tabular}{lcr}
\hline & ANNALES \\
& UNIVERSITATIS MARIAE CURIE-SKŁODOWSKA & \\
LUBLIN - POLONIA & \\
VOL. IV & SECTIO N & 2019 \\
\hline
\end{tabular}

\title{
Bernadeta Niesporek-Szamburska
}

Uniwersytet Śląski w Katowicach

ORCID: http://orcid.org/0000-0001-9935-6733

bernadeta.niesporek-szamburska@us.edu.pl

\section{Czemu służy ocenianie na uczelni - o celach i cechach oceniania z perspektywy studentów}

\author{
What is the Purpose of Assessment at the \\ University - about the Goals and Characteristics of \\ Assessment from the Students' Perspective
}

\begin{abstract}
Streszczenie: W opracowaniu przedstawiono rozważania związane z funkcjami oceniania w uczelni wyższej. Początkowe pytania o możliwości sprostania zadaniom ewaluacji w kontekście wyznaczanym przez utrwalone praktyki oceniania, zmiany związane z wdrażaniem PRK, a także przez teorię pedagogiczną (ocenianie kształtujące vs sumujące) rozstrzygnięto za pomocą badania sondażowego przeprowadzonego wśród studentów. Ich wypowiedzi, na temat m.in. czytelności systemu oceniania i ustalania jego kryteriów, trafności/przypadkowości, uśredniania ocen w OKM oraz procesualnych cech ewaluacji, prowadzą do wniosku, że studiujący potrafią docenić mierzalność oceniania sumującego (np. egzaminów testowych), ale też zgłaszają postulaty, by wyposażyć weryfikację w cechy oceniania kształtującego, wspierającego ich uczenie się.
\end{abstract}

Słowa kluczowe: ocenianie w szkole wyższej; cechy oceniania; funkcje oceniania w szkole wyższej; badanie sondażowe; ocenianie z perspektywy studenta 
Ocenianie to złożony proces, będący elementem tradycji szkoły już od prawie 100 lat i gorąco dyskutowany we współczesnej dydaktyce. Na wszystkich etapach kształcenia dość powszechnie uznaje się za konieczne owo mierzenie/weryfikację poziomu i postępów uczących się w opanowaniu wiadomości i umiejętności. Dyskusje dotyczące oceniania toczą się głównie wokół wątpliwości związanych z „odczuwaniem niesprawiedliwości przez ocenianych” oraz wokól „niedostatku obiektywizmu oceniających. To uwikłanie w złożone relacje interpersonalne i świat wartości poszerza zakres myślenia o ocenianiu o kontekst społeczny, w tym społeczne oczekiwania wobec edukacji" ${ }^{\text {. }}$

W polskich szkołach wyższych oczekiwania te zaspokaja polityka edukacyjna państwa, skupiająca się obecnie na wdrażaniu zmian związanych z funkcjonowaniem uczelni w Europejskich Ramach Kwalifikacji (ERK), zaktualizowanych w Polskiej Ramie Kwalifikacji (PRK). Treści tworzących je dokumentów obligują do przemyślenia na nowo zarówno procesu kształcenia, jak i oceniania, co może niejednokrotnie skutkować napięciami pomiędzy nowym, społecznym i uczelnianym porządkiem a długoletnią tradycją i empirią, przekazywaną i utrwaloną w zwyczajach i praktycznych działaniach pomiarowych ${ }^{2}$. Niewielki wpływ na kształcenie (w tym na ocenianie) miała do tej pory teoria pedagogiczna, słabiej rozwinięta w odniesieniu do dyskursu edukacyjnego współczesnej szkoły wyższej, choć odwoływanie się do jej ustaleń jest niezbędne, m.in. ze względu na ewolucję doktryny edukacji w tym zakresie i zmiany dotyczące samych funkcji oceniania $^{3}$. Te trzy elementy (unormowania prawne, empiria i praktyczne działania, teoria pedagogiczna) kształtują ewaluację we współczesnej uczelni wyższej.

Dotarcie do jasnego określenia tej kategorii ewaluacyjnej w regulacjach prawnych stanowi jednak pewną trudność. Brakuje w nich bowiem m.in. opisu oceniania, określenia jego celu i funkcji w weryfikacji osiągnięć studentów. W ustawie Prawo o szkolnictwie wyższym z 2012 roku ${ }^{4}$ edukacji na szczeblu wyższym wyznaczono wprawdzie ogólne ramy określające zapis programów kształcenia w postaci efektów kształcenia, a także opis procesu prowadzącego do uzyskania oraz ustalenia sposobu ich weryfikacji i potwierdzania, lecz w dokumencie tym

1 G. Szyling, Obiektywizm i sprawiedliwość - (nie)wygodne kategorie szkolnego oceniania, [w:] Sprawcy i/lub ofiary działań pozornych w edukacji szkolnej, red. M. Dudzikowa, K. Knasiecka-Falbierska, Kraków 2013, s. 255-272.

2 Por. U. Beck, A. Giddens, S. Lash, Modernizacja refleksyjna. Polityka, tradycja i estetyka w porzadku społecznym nowoczesności, Warszawa 2009.

3 T. Lewowicki, Przemiany oświaty. Szkice o ideach i praktyce edukacyjnej, Rzeszów 1994, s. $15-18$.

4 Obwieszczenie Marszałka Sejmu Rzeczypospolitej Polskiej z dnia 26 marca 2012 roku w sprawie ogłoszenia jednolitego tekstu ustawy - Prawo o szkolnictwie wyższym (Dz.U. 2012, poz. 572). 
trudno jest odszukać regulacje dotyczące oceniania studentów. Podobne zapisy odnośnie do efektów kształcenia i ich weryfikacji znajdują się w ustawie z 2018 roku $^{5}$. Tymczasem informacja na temat oceniania (np. skali ocen na uczelni, odmiennej od tej z poprzednich etapów edukacji) jest potrzebna uczestnikom interakcji dydaktycznej. Powinni ją uzyskać zarówno kandydat na studia, jak i nauczyciel akademicki. Można ją znaleźć w regulaminach studiów zatwierdzanych przez senaty poszczególnych uczelni, dlatego skale ocen bywają różne ${ }^{6}$. Czym kierują się twórcy regulaminów, gdy napotykają na wskazane niedostatki istniejących regulacji? Grażyna Szyling, poszukując precyzyjnych wytycznych do opisu oceniania studentów, znalazła pewne informacje w dokumentach Parlamentu Europejskiego, a ściślej w zaleceniach w sprawie ustanowienia europejskich ram kwalifikacji dla uczenia się przez całe życie ${ }^{7}$. Dane te pozwoliły autorce uznać kategorię oceniania osiągnięć za obecną w dokumentach ustawowych, choć jedynie w formie mało wyrazistego omówienia:

Jeśli bowiem efekty kształcenia (learning outcomes) oznaczają „zasób wiedzy, umiejętności oraz kompetencji społecznych nabytych w procesie uczenia się", to zakres znaczeniowy tego pojęcia jest zbieżny z pedagogicznym rozumieniem przedmiotu oceny, na który składają się jakościowe kryteria stanowiące punkt odniesienia dla sformułowania sądu wartościującego, czyli oceny. Zadanie uniwersytetu [...] polega na zweryfikowaniu efektów nauczania przyjętych dla danego kierunku studiów czy formy kształcenia, czyli upewnieniu się, że zostały one osiągnięte, co wymaga sprawdzania za pomocą różnych metod wiedzy, umiejętności i kompetencji społecznych posiadanych przez studentów oraz sformułowania konkluzji w postaci umownej formy oceny (stopnia, liczby punktów, procentów, opisu) ${ }^{8}$.

Wnioski G. Szyling pozwalają na stwierdzenie, że ocenianie w szkole wyższej ma umocowanie prawne, a jego podstawę stanowi odniesienie ewaluacji studenta do poziomu, na jakim osiągnął on zakładane efekty kształcenia. Już samo formułowanie efektów - odpowiednich do programu studiów, mierzalnych

5 Ustawa z dnia 20 lipca 2018 roku - Prawo o szkolnictwie wyższym i nauce (Dz.U. 2018, poz. 1668).

6 Por. np. zapis systemu ocen na Uniwersytecie Warszawskim: obwieszczenie nr 6 Rektora Uniwersytetu Warszawskiego w sprawie ogłoszenia jednolitego tekstu uchwały nr 142 Senatu Uniwersytetu Warszawskiego z dnia 18 października 2006 roku w sprawie uchwalenia Regulaminu Studiów na Uniwersytecie Warszawskim (Monitor Uniwersytetu Warszawskiego, nr 5B, poz. 134).

7 Por. zalecenie PE i RE z dnia 23 kwietnia 2008 roku w sprawie ustanowienia europejskich ram kwalifikacji dla uczenia się przez całe życie (Dz.Urz. UE C 111, 6.05.2008, s. 1-7).

8 G. Szyling, Pytania o ocenianie w szkole wyższej. Zarys zagadnienia, „Dyskursy Młodych Andragogów” 2015, nr 16, s. 10-11. 
i obserwowalnych, a także możliwych do oceny - odsyła do teorii pedagogicznej. W opisie procesu bolońskiego skorzystano z teorii taksonomii celów edukacyjnych Benjamina Blooma9 ${ }^{9}$. Mówiąc o nauczaniu, podkreślił on, że uczenie się jest procesem, w którym weryfikacja wiedzy i umiejętności powinna prowadzić do rozwoju sposobu rozumowania oraz osiągania przez uczącego się wyższych etapów syntezy i oceny ${ }^{10}$, a w takim przypadku ocenianie nie powinno być jednorazowym aktem wystawienia stopnia odpowiadającego poziomowi kompetencji adepta, lecz procesem.

Dla wyznaczenia miejsca ewaluacji w procesie kształcenia istotne są również cele, jakim ma ona służyć. W „Perspektywie uczenia się przez całe życie” wyodrębniono pięć zadań istotnych dla tego programu ${ }^{11}$. Pierwsze z nich, odnoszone do kompetencji i kwalifikacji, kładzie nacisk na „kreatywność i innowacyjność”, wymaga też indywidualnego podejścia do studentów, rozwijania zdolności do pracy w zespole oraz wspierania postawy otwartości wobec uczenia się aktywnego i praktycznego. Drugie dotyczy zbudowania przejrzystego i spójnego krajowego systemu kwalifikacji, służącego „realizacji procedur oceny i potwierdzania osiągnięć osób uczących się pod kątem efektów uczenia się, tj. niezależnie od miejsca, sposobu i czasu uczenia się, kształcenia i szkolenia (stosowanie otwartego podejścia do nadawania kwalifikacji)"12 możliwie uogólnionych, przejrzystych i wiarygodnych dla ocenianych kompetencji. Te dwa cele ogólne uczenia się tworzą według G. Szyling dwie skrajne koncepcje w obrębie kształcenia uniwersyteckiego, trudne do pogodzenia, „ponieważ odmiennie pojmują rozwój uczącego się, inaczej definiują wiedzę i program kształcenia, a także ustanawiają inne relacje między studentem i nauczycielem akademickim"13. Z jednej strony ocenianie służy więc „przejrzystemu” i „obiektywnemu” mierzeniu założonych dla kierunku ujednoliconych efektów, kontroli wyników ich opanowania lub poprawiania, aby uzyskać bliskość z oczekiwanym (w zależności od zmiennych potrzeb rynku pracy) wzorcem, z drugiej zaś ma służyć motywowaniu do rozwijania innowacyjności i samodzielności oraz zindywidualizowanemu wspieraniu studenta w uczeniu się.

9 Odwołano się do taksonomii celów edukacyjnych B. Blooma (głównie w obszarze oceny uczenia się). Por. B. Bloom, Taxonomy of Educational Objectives. The Classification of Educational Goals, New York 1969.

10 D. Kennedy, Writing and Using Learning Outcomes. A Practical Guide, Ireland 2007, s. $26-27$.

11 Załącznik do uchwały nr 160/2013 Rady Ministrów z dnia 10 września 2013 roku „Perspektywa uczenia się przez całe życie", https://archiwum.men.gov.pl/wp-content/uploads/2014/01/ plll_2013_09_10zal_do_uchwaly_rm.pdf [dostęp: 1.09.2018].

12 Ibidem, s. 36.

13 G. Szyling, Pytania o ocenianie..., s. 12. 
Ukierunkowanie celów oceniania w programach kształcenia wydaje się zatem w szkolnictwie wyższym dość rozbieżne. To, którą z dwóch dość odległych tendencji w ocenianiu preferują w praktyce studenci, spróbuję określić, wspomagając się ich opiniami i oceną wystawioną przez nich systemowi ewaluacji. Posłużę się przykładem niewielkiego badania przeprowadzonego wśród studentów Wydziału Filologicznego (obecnie: Wydziału Humanistycznego) Uniwersytetu Śląskiego. Wszak analiza zadowolenia studentów ze studiowania oraz poznanie ich opinii na temat mierzalności uzyskiwanych kompetencji i wypracowanych podczas studiów postaw stały się w ostatnim czasie jednymi z najistotniejszych elementów oceny jakości kształcenia ${ }^{14}$.

Badanie diagnozujące przeprowadzono wśród 95 uczących się, w tym 66 studentów studiów I stopnia (licencjat), mniej doświadczonych, oraz 29 studiujących na II poziomie (studia magisterskie uzupełniające), zaznajomionych z procedurami oceniania na uczelni ${ }^{15}$. Respondenci zostali poproszeni o wypełnienie ankiety składającej się z 12 pytań (otwartych i zamkniętych). Zapytano ich o czytelność samego systemu oceniania oraz o zadowolenie z procesu, w trakcie którego ocenia się przede wszystkim opanowaną przez nich wiedzę i umiejętności.

Pierwsze pytania dotyczyły rozumienia uczelnianego systemu oceniania oraz wiedzy o nim, a w poszczególnych modułach - zgodności z sylabusem (tab. 1 i 2).

Tab. 1. Czytelność systemu oceniania w ocenie studentów*

\begin{tabular}{|l|c|c|}
\hline \multicolumn{1}{|c|}{ 1. System oceniania jest: } & Studenci studiów I stopnia & Studenci studiów II stopnia \\
\hline czytelny, zrozumiały & $61(92,4 \%)$ & $23(79,3 \%)$ \\
\hline nieczytelny, niezrozumiały & $3(4,5 \%)$ & $5(17,3 \%)$ \\
\hline inne odpowiedzi** & $1(1,5 \%)$ & - \\
\hline brak odpowiedzi & $1(1,5 \%)$ & $1(3,4 \%)$ \\
\hline
\end{tabular}

* numeracja tytułu wiersza odpowiada kolejności pytań ankiety (sparafrazowanych na użytek tabel);

** inne: idiotyczny; to zależy

Źródło: opracowanie własne.

14 Ocenianie jest jednym z najważniejszych elementów pracy dydaktycznej na uczelni. To jedno z kryteriów, według którego oceniani są również nauczyciele akademiccy.

15 Badani z I i II roku studiów I stopnia (63 studentki i 3 studentów) z kierunków: filologia polska, komunikacja promocyjna i kryzysowa, bibliotekoznawstwo, a także studiujący na II poziomie na I i II roku (26 studentek i 3 studentów) z kierunków: filologia polska, studia międzynarodowe polskie, zostali poproszeni pod koniec roku akademickiego 2017/2018 o wypełnienie ankiety na temat oceniania. 
Tab. 2. Kryteria oceniania modułów, przedmiotów, zadań

\begin{tabular}{|l|c|c|}
\hline $\begin{array}{c}\text { 2. Kryteria oceniania modu- } \\
\text { łów, przedmiotów, zadań: }\end{array}$ & Studenci studiów I stopnia & Studenci studiów II stopnia \\
\hline wynikają z sylabusa & $16(24,2 \%)$ & $8(27,6 \%)$ \\
\hline $\begin{array}{l}\text { są ustalane z prowadzącym na } \\
\text { bieżąco }\end{array}$ & $49(74,2 \%)$ & $21(72,4 \%$ \\
\hline brak odpowiedzi & $1(1,5 \%)$ & - \\
\hline $\begin{array}{c}\text { 3. Ocenianie przedmiotu i/lub } \\
\text { modułu jest: }\end{array}$ & Studenci studiów I stopnia & Studenci studiów II stopnia \\
\hline zgodne z sylabusem & $55(83,3 \%)$ & $18(62,1 \%)$ \\
\hline niezgodne z sylabusem & $6(9,1 \%)$ & $6(20,7 \%)$ \\
\hline inne $^{*}$ & $5(7,6 \%)$ & $5(17,2 \%)$ \\
\hline
\end{tabular}

* inne: różne; czasami nie ma w ogóle sylabusa; zależy od przedmiotu; nie wiem

Źródło: opracowanie własne.

Odpowiedzi studentów wskazują, że dobrze poznali system. Zadziwiające jest to, że wątpliwości do narzuconej organizacji ewaluowania osiągnięć częściej zgłaszali starsi respondenci (wyższy procent wskazań - 17,3\%), podczas gdy młodsi studiujący prawie bez wyjątku potwierdzili znajomość systemu (aż 92,4\%). Takie wyniki mogą sugerować istnienie określonego poziomu niezadowolenia z oceniania, przy czym jedynie bardziej doświadczeni studenci otwarcie je wyrażali. Wniosek wydaje się uprawniony, ponieważ studenci zapytani o kryteria oceniania odpowiedzieli, że ustala się je na bieżąco z prowadzącym (tak stwierdziło ponad 74\% młodszych i ponad 72\% starszych ankietowanych); zdarza się też, że przyjęte kryteria oceniania odbiegają od podanych w sylabusie (zdaniem 9,1\% młodszych i 20,7\% starszych studentów).

Do etapu wstępnego należało również pytanie o ocenę końcową modułu, uśredniającą składowe przedmiotowe (tab. 3), którą - jak widać z rezultatów studenci w większości przyjmują dobrze, choć ponad 30\% respondentów z obu grup zakwestionowało takie rozwiązanie, utrzymując, że uśredniający system gubi informacje o ich indywidualnych zainteresowaniach, a także nie pokazuje ich wkładu pracy w różne formy zajęć. Przykładowe wypowiedzi: wszelkie uśrednianie jest krzywdzace; skoro sa 2 przedmioty z różnymi kryteriami, to oceny też mogtyby być dwie; $z$ każdego przedmiotu sq realizowane inne treści i wobec tego sq inne wymagania; uśrednianie jest niewtaściwe, ponieważ student wykonuje większa ilość pracy, a ocena jest tylko jedna; wykładowcy często sami ustalaja czy wyktad, ćwiczenia sq ważniejsze i psuja nam tym szanse na stypendium; nie zawsze sa właściwe kryteria - waga ocen; bo nie pokazuje się zainteresowań studenta. 
Tab. 3. Opinie studentów na temat oceny końcowej modułu

\begin{tabular}{|l|c|c|}
\hline $\begin{array}{c}\text { 4. Uśrednianie ocen z modu- } \\
\text { łów jest właściwe }\end{array}$ & Studenci studiów I stopnia & Studenci studiów II stopnia \\
\hline Tak & $45(68,2 \%)$ & $19(65,5 \%)$ \\
\hline Nie & $20(30,3 \%)$ & $10(34,5 \%)$ \\
\hline Brak odpowiedzi & 1 & - \\
\hline
\end{tabular}

Źródło: opracowanie własne.

Uzasadnienia odpowiedzi studentów:

1. Odpowiedzi „tak":

a) licencjat:

- poniewaź średnia ocena pozwala wykazać średniq wiedzę studenta; jest to jeden przedmiot realizowany $w$ dwóch formach.

2. Odpowiedzi „nie”:

a) licencjat:

- różne oceny maja różnq wartość; wszelkie uśrednianie jest krzywdzace,

- problematyczne, na innych uczelniach tego nie ma,

- skoro sá 2 przedmioty z różnymi kryteriami, to oceny też mogtyby być dwie,

- $z$ każdego przedmiotu sq realizowane inne treści $i$ wobec tego sq inne wymagania; ponieważ każdy przedmiot wymaga innej wiedzy i zaangażowania. Nie powinno się ich zrównywać,

- każdy przedmiot ma swoja wagę trudności. Nie można porównywać części trudniejszych przedmiotów do tych łatwiejszych,

- ponieważ praca na każdym przedmiocie powinna byćbrana pod uwage oddzielnie,

- ponieważ student wykonuje większą ilość pracy, a ocena jest tylko jedna,

- wyktadowcy często sami ustalają czy wyktad, ćwiczenia sq ważniejsze i psuja nam tym szanse na stypendium,

- niesprawiedliwe; ponieważ prowadzacy prowadza inaczej przedmioty;

b) magisterskie uzupełniające:

- bo sa różni prowadzacy i różnie oceniaja,

- każdy przedmiot powinien być traktowany osobno,

- nie zawsze sa wtaściwe kryteria - waga ocen,

- bo nie pokazuje się zainteresowań studenta.

Wątpliwości studentów dotyczące uśredniania wydają się w znacznej mierze słuszne, ponieważ dbałość o przejrzystość informacyjną, jaką powinna zawierać 
ocena, zostaje zredukowana do ujednoliconej formy stopnia określającego poziom osiągnięć uczącego się, nałożonej na nachodzące na siebie kategorie efektów kształcenia. Tymczasem, jak wskazują pedagodzy, ocena i odpowiedni do niej komentarz, precyzujący osiągnięcia, mogą zachęcić uczących się do samodzielnej pracy, do zainteresowania się tematem, a nawet do wyjścia poza materiał omawiany na zajęciach ${ }^{16}$.

Następne pytania ankiety dotyczyły pośrednio funkcji oceniania: otwierania przestrzeni dialogu, kreowania samodzielności studenta i wpływania na jego postawę społeczną, określenia się w odniesieniu do innych uczestników zajęć, a także przekonania o własnych możliwościach. Taka rola oceniania prowadzi do umiejętności (ważnej w przyszłej pracy zawodowej) kierowania własnym rozwojem. W procesie ewaluacji zostaje ona uruchomiona przez możliwość wspólnego ustalania kryteriów ocen, podstawową do przejmowania przez studiujących pełnej kontroli nad przebiegiem nauki i przynoszącą im zwykle większą satysfakcję. Możliwości takiej dotyczyło piąte pytanie ankiety ${ }^{17}$ (tab. 4).

Tab. 4. Możliwość wspólnego formułowania kryteriów oceny na zajęciach

\begin{tabular}{|l|c|c|}
\hline $\begin{array}{c}5 . \text { Możliwość formułowania } \\
\text { kryteriów oceny na zajęciach }\end{array}$ & Studenci studiów I stopnia & Studenci studiów II stopnia \\
\hline Tak & $24(36,4 \%)$ & $11(37,9 \%)$ \\
\hline Nie & $43(65,2 \%)$ & $17(58,6 \%)$ \\
\hline Brak odpowiedzi & - & $1(3,4 \%)$ \\
\hline
\end{tabular}

Źródło: opracowanie własne.

Z uzasadnień odpowiedzi twierdzącej studentów studiów magisterskich uzupełniających wynika, że np. można:

- ustalić, za co będzie ocena i to, co można zrobić, by ja podnieść (np. prezentacja),

- wybrać warunki zaliczenia (kolokwium lub praca zal.).

Niestety, odpowiedzi respondentów nie napawają optymizmem, gdyż większość z nich (65,2\% młodszych i 58,6\% starszych) nie ma wpływu na kryteria oceniania. Fakty te świadczą o tym, że uczelnianej ewaluacji nie oparto na współczesnej myśli dydaktycznej, mocno promującej już na niższych etapach nauczania ocenianie kształtujące, rozumiane jako ocenianie służące uczeniu się (powiązane

16 J. Hattie, Visible Learning. A Synthesis of Over 800 Meta-Analyses Relating to Achievement, Routledge 2008.

17 Pytanie piąte miało formę zamkniętą: Na zajęciach jest możliwość formułowania kryteriów oceny, np. zadań czy projektów (tak, nie). Studenci mogli jednak uzupełnić odpowiedź własnym uzasadnieniem. 
m.in. z planowaniem i podsumowaniem osiągnięć, a także z uzgadnianiem kryteriów $)^{18}$. Wraz z intensywnym promowaniem nowej idei oceniania wyraźnie rysuje się w edukacji podział na ocenianie sumujące i kształtujące ${ }^{19}$. To pierwsze wycenia jedynie stopień opanowania wiedzy, podczas gdy drugie kładzie nacisk na jej rozwijanie ${ }^{20}$. Swoistą popularność oceniania sumującego dowodzą kolejne opinie badanych. W wymiarze etycznym uznali oni bowiem ewaluację za niesprawiedliwą w znacznym stopniu ${ }^{21}$, o czym świadczą dane zamieszczone w tab. 5 .

Tab. 5. Czy oceny uzyskiwane w procesie kształcenia na uczelni są sprawiedliwe?

\begin{tabular}{|l|c|c|c|c|}
\hline 6. Ocenianie na uczelni & \multicolumn{2}{|c|}{ Sprawiedliwe } & Niesprawiedliwe & \multicolumn{2}{|c|}{ Sprawiedliwe } & Niesprawiedliwe \\
\hline przy ocenianiu: & \multicolumn{2}{|c|}{ studenci studiów I stopnia } & \multicolumn{2}{|c|}{ studenci studiów II stopnia } \\
\hline zadań & $28(42,4 \%)$ & $18(27,3 \%)$ & $6(20,7 \%)$ & $4(13,8 \%)$ \\
\hline prac & $28(42,4 \%)$ & $22(33,3 \%)$ & $3(10,3 \%)$ & $4(13,8 \%)$ \\
\hline przedmiotów & $23(34,8 \%)$ & $21(31,8 \%)$ & $2(6,9 \%)$ & $2(6,9 \%)$ \\
\hline egzaminów & $45(68,2 \%)$ & $10(15,2 \%)$ & $17(58,6 \%)$ & $5(17,2 \%)$ \\
\hline całego modułu & $19(28,8 \%)$ & $10(15,2 \%)$ & $1(3,4 \%)$ & $12(41,4 \%)$ \\
\hline inne & - & $5(7,6 \%)$ & - & $2(6,9 \%)$ \\
\hline
\end{tabular}

Źródło: opracowanie własne.

Młodsi studenci jako najbardziej niesprawiedliwe wskazali ocenianie różnego rodzaju prac (33,3\%) oraz przedmiotów, starsi zaś ocenianie całych modułów $(41,4 \%)$, co zdaje się potwierdzać niezgodę na uśrednianie ocen w ramach OKM (oceny końcowej modułu).

18 Por. G. Czetwertyńska, Ocenianie jako nauczanie i uczenie się, „Języki Obce w Szkole” 2015, nr 3, s. 5.

19 Różnice pomiędzy kategoriami oceniania: ocenianie sumujące dotyczy przede wszystkim podsumowywania etapów pracy z uczniem, kończy nauczanie danego modułu, pracę semestralną lub cykl kształcenia, a o cenianie kształtujące to integralna część samego procesu dydaktycznego. Ocenianie sumujące ma za zadanie w danym momencie wycenić stopień opanowania danego fragmentu materiału i poziomu wiedzy, natomiast zadanie oceniania kształtującego polega na rozwijaniu tej wiedzy i umiejętności, a sam moment oceny traci w nim swą istotność, gdyż rzeczywiście istotna jest częstotliwość wyznaczająca dynamikę uczenia się. Por. ibidem, s. 5-6.

20 Elementy konieczne oceniania kształtującego: „1) planowanie i formułowanie celów oraz kryteriów wykonania z udziałem uczniów; 2) efektywna informacja zwrotna; 3) refleksja i dyskusja na temat rezultatów uczenia się, do której obok uczniów włącza się rodziców; 4) kluczowe pytania, dzięki którym można rozpoznać, czy uczeń rzeczywiście zrozumiał daną partię materiału, omawiane zagadnienie, prezentowany problem; 5) reguły, metody i techniki pracy na lekcji mające służyć włączaniu do pracy wszystkich uczniów, zachęcaniu do współpracy i samodzielności; 6) stosowanie samooceny i oceny koleżeńskiej” (ibidem, s. 7).

21 „Sprawiedliwą" w wymiarze społecznym, kiedy sprawiedliwość uznaje się za prawidłową partycypację w dostępie do przywilejów, dóbr, zasług itp. Por. W. Sztumski, Bezprawie i niesprawiedliwość, „Sprawy Nauki” 2018, nr 4. 
Za najbardziej sprawiedliwie oceniany w obu grupach respondentów uznano egzamin (68,2\% młodszych i 58,6\% starszych badanych). Był on wymieniany równie często przy pytaniu otwartym jako jedna z najsprawiedliwszych metod sprawdzania kompetencji. Z jednej strony wynik ten może dowodzić rzetelności w zakresie mierzalności kompetencji (głównie wiedzy) przez egzaminy (zwłaszcza testowe), z drugiej jednak rzetelność, uznawana potocznie za powtarzalność pomiaru, a więc możliwą podstawę porównywalności wyników egzaminu i różnicowania poziomu osiągnięć uczących się,22, może świadczyć o już „zakonserwowanych”, reaktywnych postawach studentów wobec uczenia się, wytworzonych w procesie oceniania na wcześniejszych etapach edukacji, gdyż wiąże „stopnie szkoln[e] z określoną treścią kształcenia”, a „o uczniu uzyskującym każdy stopień [pozwala] [...] zasadnie wnioskować, jakie elementy tej treści opanował, a jakich nie opanował” ${ }^{23}$. „Stopień jest w tym wypadku formą wyrażania oceny (a nie oceną samą w sobie), rodzajem konkluzji, w której określa się poziom osiągnięć studenta, zapisywany w dokumentacji o różnym zakresie sformalizowania" ${ }^{24}$, z kolei „treści kształcenia” stanowią w zreformowanej szkole wyższej zakres merytoryczny programu studiów powiązany z efektami kształcenia (w zakresie wiedzy, umiejętności i kompetencji społecznych). Stopień werbalizuje zatem jakość opanowania treści, a powiązanie z rzetelnością czyni zeń doskonałe narzędzie weryfikacji efektów kształcenia - przejrzyste i mierzalne. Sposób wystawiania ocen wiąże też sam proces weryfikacji z tradycyjnie niesymetryczną relacją pomiędzy nauczycielem akademickim a studentem oraz wskazuje na panowanie tego pierwszego nad kontekstem weryfikowania wiedzy $^{25}$. „Ten rodzaj interakcji, zakończony wystawieniem formalnej i bezdyskusyjnej oceny, którą można zmienić tylko na drodze obowiązujących procedur, jest właściwy właśnie sytuacjom egzaminacyjnym"26, ma jednak niewiele wspólnego z drugim celem oceniania, a mianowicie ze wzmacnianiem samodzielności uczących się. Respondenci opowiedzieli się w tym przypadku za ocenianiem jako systemowym i przejrzystym „mierzeniem” opanowania efektów kształcenia.

Dalsze dowody na niewiązanie oceniania z potrzebą stymulowania innowacyjności, samodzielności i „indywidualizacji w podejściu do uczących się" przynoszą kolejne odpowiedzi, które tym razem ukazują, że studenci wysoko ocenili (aż 68,2\% odpowiedzi młodszych i 55,2\% starszych badanych; tab. 6) możliwość uzyskania

22 Por. B. Niemierko, Ocenianie szkolne bez tajemnic, Warszawa 2002, s. 170-180.

23 Ibidem, s. 223.

24 G. Szyling, Pytania o ocenianie..., s. 15.

25 K. Konarzewski, Dylematy oceniania osiagnięć szkolnych, „Kwartalnik Pedagogiczny” 1999, nr 2, s. 35.

26 G. Szyling, Pytania o ocenianie..., s. 14. 
wraz z oceną informacji zwrotnej - jednego z czynników warunkujących ocenianie kształtujące. Jednocześnie, głównie młodsi respondenci, skarżyli się, że informacji takiej nie otrzymują. Na ten fakt wskazało 56,0\% młodszych i 31,0\% starszych ankietowanych (tab. 7). Należy jeszcze zaznaczyć, że nie zawsze student ma możliwość poprawienia oceny (drugi ceniony przez respondentów czynnik; tab. 6). Tymczasem to właśnie takie komponenty oceniania, jak szybka informacja zwrotna (odniesiona do ustalonych kryteriów, w które uczący się powinni zostać zaopatrzeni) oraz możliwość rozwinięcia swej wiedzy i zmiana oceny łączą wątek uczenia się aktywnego i praktycznego z indywidualnym wymiarem celów sformułowanych w strategii uczenia się przez całe życie. Informacja umożliwia również podjęcie dyskusji z prowadzącym, co może kształcić samoocenianie czy ocenianie koleżeńskie. Właściwości te, należące do oceniania kształtującego, mogą wzmacniać u studentów poczucie sprawstwa i niezależności - postawy urzeczywistniającej zakres efektów zaliczanych do kompetencji społecznych ${ }^{27}$. Tym razem respondenci opowiedzieli się za ocenianiem rozumianym jako wsparcie studenta w nauce i dążeniu do innowacyjności.

Tab. 6. Czynniki motywujące studentów do uczenia się

\begin{tabular}{|l|c|c|}
\hline \multicolumn{1}{|c|}{$\begin{array}{c}\text { 7. Ocena wspiera Twoje } \\
\text { uczenie się, gdy: }\end{array}$} & Studenci studiów I stopnia & Studenci studiów II stopnia \\
\hline $\begin{array}{l}\text { wraz z oceną otrzymuję infor- } \\
\text { mację zwrotną }\end{array}$ & $45(68,2 \%)$ & $16(55,2 \%)$ \\
\hline $\begin{array}{l}\text { mam możliwość poprawienia } \\
\text { oceny }\end{array}$ & $19(28,8 \%)$ & $9(31,0 \%)$ \\
\hline inne & $2(3,0 \%)$ & $1(3,4 \%)$ \\
\hline brak odpowiedzi & - & $3(10,3 \%)$ \\
\hline
\end{tabular}

* inne, np.: nie wspiera, bo jest niesprawiedliwa; informacja zwrotna nie występuje; nie wspiera, znacznie bardziej wspiera np. ocenianie aktywności

Źródło: opracowanie własne.

Wskazania badanych dotyczyły też przypadkowości oceny, jej swoistej „nietrafności”28, kiedy w zdecydowanej większości (54,5\% młodszych i 65,5\% starszych respondentów) wskazali na zróżnicowanie ocen za tak samo wykonane zadanie (tab. 7). Studenci przeżywają fakt zróżnicowania ocen, a także form

27 S. Brookhart, Editorial, "Educational Measurement: Issues and Practices” 2009, Vol. 28(1), DOI: https://doi.org/10.1111/j.1745-3992.2009.01131.x, s. 2.

28 Trafność - rozumiana najczęściej jako stopień, w jakim mierzy się to, co jest celem pomiaru, jako zakres, w którym wyjaśnienie odzwierciedla właściwie zjawisko, do jakiego się odwołuje. Por. D. Silverman, Interpretacja danych jakościowych, Warszawa 2009, s. 252-261. 
weryfikacji bardzo emocjonalnie, np.: Jedni maja kolokwium, inni piatki „bo tak”. To niedopuszczalne! Powinno się to ujednolicić i kontrolować.

Tymczasem nauczyciele akademiccy zdają sobie sprawę, że nawet w sytuacjach trudnych do rozstrzygnięcia istnieją odpowiednie rozwiązania dydaktyczne, np. podczas weryfikacji zadań, w których kryteria oceniania nie do końca poddają się obiektywizacji, można włączyć ocenę koleżeńską i samoocenę (przy jednoczesnym budowaniu dobrych relacji w grupie).

Tab. 7. Trafność a przypadkowość oceny

\begin{tabular}{|l|c|c|}
\hline \multicolumn{1}{|c|}{ 8. Przypadkowość oceny } & Studenci studiów I stopnia & Studenci studiów II stopnia \\
\hline $\begin{array}{l}\text { Nie wiesz, z czego wynika, brakuje } \\
\text { informacji zwrotnej }\end{array}$ & $37(56,0 \%)$ & $9(31,0 \%)$ \\
\hline $\begin{array}{l}\text { Kolega/koleżanka za tak samo } \\
\text { rozwiązane zadanie lub problem } \\
\text { otrzymał/otrzymała ocenę wyższą }\end{array}$ & $36(54,5 \%)$ & $19(65,5 \%)$ \\
\hline $\begin{array}{l}\text { Nie masz możliwości wpłynięcia na } \\
\text { jej zmianę }\end{array}$ & $13(19,7 \%)$ & $9(31,0 \%)$ \\
\hline Inne* & $3(4,5 \%)$ & - \\
\hline Brak odpowiedzi & - & $3(10,2 \%)$ \\
\hline
\end{tabular}

* inne: czasem ten sam modut u innego nauczyciela ma inne wymagania; Jedni mają kolokwium, inni piątki „bo tak”. To niedopuszczalne! Powinno się to ujednolicić i kontrolować

Źródło: opracowanie własne.

Respondentów poproszono również o zweryfikowanie faktu, czy ocenianie staje się w szkole wyższej procesem oraz czy wykorzystuje się je (jak w ocenianiu kształtującym) podczas całego okresu kształcenia (od planowania po podsumowanie i w miarę często). Do zbadania tego problemu posłużyły pytania dotyczące określenia liczby i jakości ocenianych w module zadań i prac.

W obu grupach studenci odpowiedzieli podobnie. Najczęściej w modułach/ przedmiotach uznawanych za dobrze/sprawiedliwie oceniane nauczyciele włączali 3-4, a rzadziej 2 sposoby weryfikacji (tab. 8, pytanie 9). I odwrotnie: w modułach uznawanych przez ankietowanych za oceniane niewłaściwie prowadzący stosowali najczęściej 1-2 sposoby. Większa liczba zadań weryfikujących efekty służyła więc nie tylko procesualności oceniania, lecz także zyskała aprobatę uczących się, którzy zaakceptowali ten rodzaj postępowania dydaktycznego i wartościowali go pozytywnie.

W obu przypadkach, tzn. podczas stosowania większej lub mniejszej liczby narzędzi weryfikujących w modułach, przeważająca część nauczycieli akademickich nie stosowała już żadnych dodatkowych sposobów weryfikacji. Fakt ten odnotowało 59,0\% młodszych i 69,0\% starszych respondentów w odniesieniu do 
modułów ocenianych właściwie, oraz odpowiednio 57,6\% i 48,3\% respondentów w odniesieniu do źle ocenianych modułów (tab. 8, pytanie 10). Jeśli jednak wprowadzano dodatkowe kryteria oceny, to studenci zauważali, że w modułach uznanych przez nich za oceniane sprawiedliwie były to zwykle kolejne sposoby weryfikacji (obecność, odnotowana aktywność, referaty). Z kolei w modułach uznawanych za ewaluowane niesprawiedliwie dodatkowymi przesłankami oceny stawały się: brak obiektywizmu ze strony prowadzącego, jego stronniczość, a wreszcie przypadkowe zadanie, które - podane jako nieobowiązkowe - stawało się podstawowym kryterium wpływającym na wysoką ocenę (tab. 8, pytanie 10).

Tab. 8. Liczba i kategorie komponentów składających się na ocenę końcową w module/przedmiocie

\begin{tabular}{|l|c|c|c|c|}
\hline 9. Komponenty i oceniane zadania stanowiące podstawę oceny końcowej modułu/przedmiotu \\
\hline \multirow{2}{*}{$\begin{array}{c}\text { liczba } \\
\text { komponentów }\end{array}$} & $\begin{array}{c}\text { najsprawiedliwiej } \\
\text { ocenianego }\end{array}$ & $\begin{array}{c}\text { niesprawiedliwie } \\
\text { ocenianego }\end{array}$ & $\begin{array}{c}\text { najsprawiedliwiej } \\
\text { ocenianego }\end{array}$ & $\begin{array}{c}\text { niesprawiedliwie } \\
\text { ocenianego }\end{array}$ \\
\cline { 2 - 5 } & studenci studiów I stopnia & studenci studiów II stopnia \\
\hline 1 & $4(6,0 \%)$ & $26(39,4 \%)$ & - & $12(41,4 \%)$ \\
\hline 2 & $19(28,8 \%)$ & $22(33,3 \%)$ & $1(3,4 \%)$ & $13(44,8 \%)$ \\
\hline $3-4$ & $27(40,9 \%)$ & $16(24,2 \%)$ & $19(65,5 \%)$ & $4(13,8 \%)$ \\
\hline 5 i więcej & $12(18,2 \%)$ & $2(3 \%)$ & $9(31,0 \%)$ & - \\
\hline Brak odpowiedzi & $4(6,0 \%)$ & - & - & - \\
\hline \multicolumn{1}{|c|}{10. Czy na ocenę końcową z modułu/przedmiotu mają wpływ inne kryteria? } \\
\hline Tak & $22(33,3 \%)$ & $13(19,7 \%)$ & $6(20,7 \%)$ & $9(31 \%)$ \\
\hline Nie & $39(59,0 \%)$ & $38(57,6 \%)$ & $20(69, \%)$ & $14(48,3 \%)$ \\
\hline Brak odpowiedzi & - & $15(22,5 \%)$ & $3(10,2 \%)$ & $6(20,4 \%)$ \\
\hline \multicolumn{5}{|c|}{11. Jakie typy zadań podlegaja ocenie na tym przedmiocie lub w tym module? } \\
\hline $\begin{array}{l}\text { Do samodzielne- } \\
\text { go wykonania }\end{array}$ & $48(52,2 \%)$ & $37(45,6 \%)$ & $7(24,1 \%)$ & $12(41,4 \%)$ \\
\hline $\begin{array}{l}\text { Do wykonania } \\
\text { w grupie }\end{array}$ & $23(25,0 \%)$ & $11(13,6 \%)$ & $13(44,8 \%)$ & $1(3,4 \%)$ \\
\hline $\begin{array}{l}\text { Trudne: projekto- } \\
\text { we, twórcze }\end{array}$ & $10(10,9 \%)$ & $9(11,1 \%)$ & $9(31 \%)$ & $8(27,6 \%)$ \\
\hline $\begin{array}{l}\text { O niewielkim } \\
\text { stopniu trudności }\end{array}$ & $5(5,4 \%)$ & $7(8,6 \%)$ & - & $5(17,2 \%)$ \\
\hline Inne & $4(6,0 \%)$ & $4(6.0 \%)$ & $2(6,8 \%)$ & $1(3,4 \%)$ \\
\hline Brak odpowiedzi & $3(4,5 \%)$ & $13(19,7 \%)$ & - & $2(6,8 \%)$ \\
\hline
\end{tabular}

Rozszerzenia odpowiedzi studentów: 10. Dodatkowe kryteria w dobrze ocenianym module: obecność; aktywność; kolokwia; praca na zajęciach; zaangażowanie; przygotowanie; ocena zćwiczeń; zadanie dodatkowe; referaty; 10. Dodatkowe kryteria w źle ocenianym module: ocena z ćwiczeń; ocena z egzaminu; filmik dla chętnych; głośno wyrażone przekonanie, że zastużyto się na ocenę; sympatia prowadzacego; 11. Inne zadania w dobrze ocenianym module: kartkówki; gry dydaktyczne; prezentacje; aktywność (plusowanie); teksty na zajęciach; 11. Inne zadania w źle ocenianym module: obejrzenie filmu; prezentacje; tylko kolokwia Źródło: opracowanie własne. 
Warto jeszcze spojrzeć na to, jakiego typu zadania wprowadzano jako narzędzia weryfikacji efektów modułowych (tab. 8, pytanie 11). Wprawdzie w modułach uznanych przez młodszych badanych za oceniane sprawiedliwie dominowały zadania do samodzielnego rozwiązania (52,2\%), jednak zadań rozwiązywanych $\mathrm{w}$ grupie było w nich dwa razy więcej niż tego typu ćwiczeń w modułach określanych jako oceniane niesprawiedliwie (25,0\% do 13,6\%). O jeszcze większej dominacji zadań zespołowych na zajęciach informują odpowiedzi starszych studentów. Zadania te występowały w modułach trafnie ocenianych ponad dziesięciokrotnie częściej. Obie grupy respondentów nie dostrzegły natomiast różnicy w częstości i roli zadań trudnych i łatwych w procesie oceniania.

Ogólnie wyniki wskazujące na różne typy ćwiczeń w modułach odbieranych jako oceniane sprawiedliwie i niesprawiedliwie świadczą w przypadku tych pierwszych o sprzyjaniu dobrym relacjom w grupie, a także - ponownie - o wdrażaniu uczących się do oceny koleżeńskiej w czasie pracy. Można również dostrzec komponenty oceniania kształtującego w charakterystyce narzędzi weryfikujących przedmiotów uznanych za trafnie oceniane.

Cenne są też uwagi studentów wyrażone w odpowiedzi na pytanie otwarte dotyczące sprawiedliwości i niesprawiedliwości oceniania ${ }^{29}$. Spostrzeżenia te odnoszą się do wielu problemów. Przede wszystkim daje się w nich wyczuć poza wyrażoną precyzyjnie prośbą o jasno wyartykułowane i stałe (niezmienne) kryteria oceniania czy o zróżnicowanie form zadań sprawdzających - tęsknotę ankietowanych do indywidualnej oceny ich własnej pracy oraz do oceniania kształtującego (ze wszystkimi komponentami, np. informacją zwrotną). Jak sami stwierdzili, chodzi im o:

- ocenianie, patrzenie na studenta indywidualnie, a nie grupowo, oceniajac jego aktywność, prace i zaangażowanie; ocenianie adekwatnie do umiejętności ocenianego; zrozumienie studenta, próbę wskazania mu ścieżki na wyższq ocenę, nieskreślanie go; indywidualne podejście do studenta, dostrzeżenie chęci studenta do nauki; ocenienie jego zaangażowania i chęci do pracy,

- uzasadnianie, dlaczego pracę oceniono w określony sposób; objaśnianie, wskazanie btędów, przyjęcie korekty; wyjaśnianie błędów, pozwalanie na ich poprawę.

Co więcej, studenci wskazali na unikanie przy ocenianiu: faworyzowania niektórych studentów; kompletnej rozbieżności przy wystawianiu ocen; braku spojrzenia na całość grupy; oceniania studenta ze względu na fakt lubienia go;

29 Pytanie 12: Co uważa Pani/Pan za najbardziej „sprawiedliwe”/niesprawiedliwe w ocenianiu (proszę krótko opisać). 
stawiania ocen „po znajomości” lub z sympatii; nierównego rozdzielania zagadnień $i$ prac; zróżnicowanego traktowania studentów na egzaminach ustnych; a nawet: zawyżania ocen osobom niepetnosprawnym.

Nadanie ocenianiu w szkole wyższej cech, o jakie upominają się studiujący, prowadzi do przechodzenia od „transparentnej »odpowiedzialności« opartej na szczegółowych kryteriach i dowodach"30, od dziesiątków narzędzi weryfikujących poszczególne efekty kształcenia do dyskursu opartego na dobrych relacjach między nauczycielem akademickim i studentem, do wzajemnego zaufania, o jakim pisał Lucien Bollaert, a nawet do powrotu do wydawałoby się staroświeckich metod nauki i sprawdzania wiedzy, jak „rozmowa i pisanie wypracowań, nazywanych esejami”31. Studenci wybierają ocenianie służące rozwijaniu innowacyjności i samodzielności, a także zindywidualizowanemu wspieraniu podczas uczenia się. Jest to bliskie weryfikacji, o której studiujący za granicą piszą: „Mojej wiedzy nikt nie testuje - skoro na jakiś temat piszę, to widać, że ją mam [...]. Ciągłe ćwiczenie w pisaniu, konfrontacja z analizą i krytyką tego, co piszę, konieczność obrony własnych tez, to coś, na co polski model studiów często kładzie zbyt mały nacisk"32.

\section{BIBLIOGRAFIA}

Beck U., Giddens A., Lash S., Modernizacja refleksyjna. Polityka, tradycja i estetyka w porzadku społecznym nowoczesności, Warszawa 2009.

Bloom B., Taxonomy of Educational Objectives. The Classification of Educational Goals, New York 1969.

Bollaert L., Quality Assurance (Qa) in Europe (2005-2015). From Internal and Institutional to External and International, "Journal of the European Higher Education Area" 2014, No. 3.

Brookhart S.M., Editorial, "Educational Measurement: Issues and Practices” 2009, Vol. 28(1), DOI: https://doi.org/10.1111/j.1745-3992.2009.01131.x.

Cieśla J., Wabiki na ajbika, „Polityka” 2018, nr 38.

Czetwertyńska G., Ocenianie jako nauczanie i uczenie się, „Języki Obce w Szkole” 2015, nr 3.

Hattie J., Visible Learning. A Synthesis of Over 800 Meta-Analyses Relating to Achievement, Routledge 2008.

Kennedy D., Writing and Using Learning Outcomes. A Practical Guide, Ireland 2007.

30 L. Bollaert, Quality Assurance (Qa) in Europe (2005-2015). From Internal and Institutional to External and International, "Journal of the European Higher Education Area" 2014, No. 3.

31 J. Cieśla, Wabiki na ajbika, „Polityka” 2018, nr 38, s. 38.

32 Ibidem. 
Konarzewski K., Dylematy oceniania osiagnięć szkolnych, „Kwartalnik Pedagogiczny” 1999, nr 2.

Lewowicki T., Przemiany oświaty. Szkice o ideach i praktyce edukacyjnej, Rzeszów 1994. Niemierko B., Ocenianie szkolne bez tajemnic, Warszawa 2002.

Obwieszczenie Marszałka Sejmu Rzeczypospolitej Polskiej z dnia 26 marca 2012 roku w sprawie ogłoszenia jednolitego tekstu ustawy - Prawo o szkolnictwie wyższym (Dz.U. 2012, poz. 572).

Obwieszczenie nr 6 Rektora Uniwersytetu Warszawskiego w sprawie ogłoszenia jednolitego tekstu uchwały nr 142 Senatu Uniwersytetu Warszawskiego z dnia 18 października 2006 roku w sprawie uchwalenia Regulaminu Studiów na Uniwersytecie Warszawskim (Monitor Uniwersytetu Warszawskiego, nr 5B, poz. 134).

Silverman D., Interpretacja danych jakościowych, Warszawa 2009.

Sztumski W., Bezprawie i niesprawiedliwość, „Sprawy Nauki” 2018, nr 4.

Szyling G., Obiektywizm i sprawiedliwość - (nie)wygodne kategorie szkolnego oceniania, [w:] Sprawcy i/lub ofiary działań pozornych w edukacji szkolnej, red. M. Dudzikowa, K. Knasiecka-Falbierska, Kraków 2013.

Szyling G., Pytania o ocenianie w szkole wyższej. Zarys zagadnienia, „Dyskursy Młodych Andragogów" 2015, nr 16.

Ustawa z dnia 20 lipca 2018 roku - Prawo o szkolnictwie wyższym i nauce (Dz.U. 2018, poz. 1668).

Zalecenie PE i RE z dnia 23 kwietnia 2008 roku w sprawie ustanowienia europejskich ram kwalifikacji dla uczenia się przez całe życie (Dz.Urz. UE C 111, 6.05.2008, s. 1-7).

Załącznik do uchwały nr 160/2013 Rady Ministrów z dnia 10 września 2013 roku „Perspektywa uczenia się przez całe życie”, https://archiwum.men.gov.pl/wp-content/uploads/2014/01/plll_2013_09_10zal_do_uchwaly_rm.pdf [dostęp: 1.09.2018].

Summary: The study presents considerations related to functions of evaluation at a university. Initial questions about the possibility of facing the tasks of evaluation in the context determined by: established assessment practices, changes related to the implementation of PRK, pedagogical theory (formative vs summation assessment) were resolved by means of a survey conducted among students. Students' statements on, i.a., the readability of the assessing system and determining its criteria, relevance/randomness, averaging ratings in the Final Module Evaluation $(\mathrm{OKM})$, processual features of evaluation, lead to the conclusion that students can appreciate the measurability of summative assessment (e.g. of test exam), but also they submit postulates to provide the verification with the features of formative assessment that supports their learning.

Keywords: assessment at a university; assessment features; assessment functions in a higher school, a survey; assessment from the student's perspective 